\title{
Analisis Faktor yang Berhubungan dengan Pemberian Imunisasi Campak pada Bayi Usia 9-12 Bulan di Puskesmas Sukakarya Kota Sabang
}

\author{
Analysis of Related Factors with Immunization of Measles in Baby Age 9-12 \\ Months in Puskesmas Sukakarya Sabang City
}

\author{
Fauziah Andika*1, Khairaniswati ${ }^{2}$ \\ ${ }^{1}$ Program Studi Ilmu Kesehatan Masyarakat, Universitas Ubudiyah Indonesia, Kota Banda Aceh, Indonesia \\ ${ }^{2}$ Puskesmas Sukakarya, Kota Sabang, Indonesia \\ *Korespondensi Penulis: fauziah@uui.ac.id
}

\begin{abstract}
Abstrak
Campak masih merupakan salah satu penyebab kematian pada anak-anak, meskipun sudah tersedia vaksin yang efektif dan aman. Di dunia diperkirakan setiap tahun terdapat 30 juta orang yang menderita campak. Tujuan penelitian ini adalah Untuk menganalisis factor yang berhubungan dengan pemberian imunisasi campak pada bayi usia 9-12 bulan di Puskesmas Sukakarya Kota Sabang. Penelitian ini bersifat kuantitatif mengunakan analitik dengan desain cross sectional. Populasi pada penelitian ini adalah seluruh ibu yang memiliki bayi berusia 912 bulan berjumlah 284 orang dengan jumlah sampel sebesar 39 Orang. Pengumpulan data diambil pada tanggal 02 Agustus s/d 05 Agustus 2017 yang dibantu oleh enumerator dengan pengolahan data menggunakan uji chi square dan CI 95\%. Hasil Penelitian ini didapat hubungan pengetahuan dengan pemberian imunisasi campak ( $\mathrm{p}$ value $=0.127$ ), hubungan sikap dengan pemberian imunisasi campak ( $\mathrm{p}$ value $=0.001)$, hubungan dukungan petugas kesehatan dengan pemberian imunisasi campak ( $\mathrm{p}$ value $=0.001)$. Kesimpulan dari penelitian ini adalah tidak ada hubungan antara pengetahuan dengan pemberian imunisasi campak, ada hubungan antara sikap dan dukungan petugas kesehatan dengan pemberian imunisasi campak. Diharapkan kepada petugas kesehatan memberikan penyuluhan kembali tentang pentingnya pemberian imunisasi campak serta memberikan dukungan kepada ibu-ibu agar termotivasi untuk memberikan imunisasi campak tepat pada waktunya.
\end{abstract}

Kata Kunci : pemberian imunisasi campak, pengetahuan, sikap dan dukungan petugas kesehatan

\begin{abstract}
Measles is still one of the causes of death in children, even though an effective and safe vaccine is available. In the world it is estimated that every year there are 30 million people who suffer from measles. The purpose of this study was to analyze factors related to measles immunization in infants aged 9-12 months at the Sukakarya Health Center in the City of Sabang. This research is quantitative using analytic with cross sectional design. The
\end{abstract}


population in this study were all mothers who had infants aged 9-12 months totaling 284 people with a sample size of 39 people. Data collection was taken on August 2 to August 5, 2017 which was assisted by enumerators by processing data using the chi square test and 95\% CI. The results of this study obtained a relationship between knowledge with measles immunization ( $p$ value $=0.127$ ), the relationship of attitudes with measles immunization ( $p$ value $=0.001)$, the relationship of support of health workers with measles immunization ( $p$ value $=0.001)$. The conclusion of this study is that there is no relationship between knowledge and measles immunization, there is a relationship between attitudes and support of health workers with the provision of measles immunization. It is expected that health workers will provide information about the importance of measles immunization and provide support to mothers to be motivated to give measles immunization on time.

Keywords: provision of measles immunization, knowledge, attitudes and support of health workers

\section{PENDAHULUAN}

Campak adalah penyakit menular yang disebabkan oleh virus (Paramyxovirus), yang lebih banyak terjadi pada anak-anak. Virus ini ditularkan melalui saluran pernapasan secara droplet dari orang yang terinfeksi. Gejala dari penyakit ini biasanya muncul 10 sampai 12 hari setelah terinfeksi, di antaranya panas tinggi, hidung berair, mata kemerahan, dan bercak putih kecil di rongga mulut. Setelah beberapa hari akan muncul bercak-bercak merah, dimulai dari muka dan leher atas dan kemudian menyebar ke bawah (WHO, 2015).

Penyakit campak akan sembuh dalam 2 sampai 3 minggu, tidak ada pengobatan yang spesifik. Pada anak yang kurang gizi dan orang yang kekebalan tubuhnya menurun bisa muncul komplikasi. Komplikasi dari penyakit campak yaitu kebutaan, ensefalitis, diare, infeksi telinga dan pneumonia. Salah satu yang berperan dalam pencegahan timbulnya komplikasi campak pada anak adalah orang tua.

Berdasarkan data dari Badan Pusat Statistik Provinsi Aceh bahwa jumlah penduduk Provinsi Aceh pada tahun 2010 adalah 4.494.400, sedangkan balita berjumlah 493.400 dan pada tahun 2011 jumlah penduduk 4.597.300 sedangkan balita berjumlah 504.700 Balita (BPS Provinsi Aceh, 2013).

Pada tahun 2013, di Indonesia dilaporkan terdapat 11.521 kasus campak, lebih rendah dibandingkan tahun 2012 yang sebesar 15.987 kasus. Jumlah kasus meninggal akibat komplikasi campak sebanyak 2 kasus, yang dilaporkan dari Provinsi Aceh dan Maluku Utara. Incidence rate (IR) campak pada tahun 2013 sebesar 4,64/100.000 penduduk, menurun 
dibandingkan tahun 2012 yang sebesar 6,53/100.000 penduduk (Profil Kesehatan Indonesia, 2013).

Tahun 2014, di Indonesia kasus campak yang rutin dilaporkan sebesar 12.222 kasus. Kasus campak rutin tersebut terbanyak dilaporkan dari Provinsi Nangroe Aceh Darussalam (1.749 kasus), Daerah Istimewa Yogyakarta (1.222 kasus), Jawa Timur (1.071 kasus). Dari seluruh kasus campak rutin tersebut, ada 7 kasus meninggal, yang dilaporkan dari Provinsi Riau (3 kasus), Kepulauan Riau (2 kasus), Sumatera Selatan (1 kasus) Provinsi Kalimantan Timur (1 kasus). KLB campak dapat terjadi apabila ada 5 atau lebih kasus klinis dalam waktu 4 minggu berturut- turut yang terjadi mengelompok dibuktikan ada hubungan epidemiologi. Frekuensi KLB campak yang terjadi di Indonesia pada tahun 2014 sebanyak 173 kejadian, dengan jumlah kasus sebanyak 2.104 kasus. Frekuensi KLB jumlah kasus pada KLB campak mengalami peningkatan dibanding tahun sebelumnya. Pada tahun 2014 kasus KLB yang telah dikonfirmasi laboratorium adalah positif campak dengan jumlah 80 kasus, sedangkan kasus rubella sebanyak 7 kasus (Ditjen P2PL, 2015).

\section{METODOLOGI}

Penelitian ini bersifat kuantitatif mengunakan analitik dengan desain cross sectional. Populasi pada penelitian ini adalah seluruh ibu yang memiliki bayi berusia 9-12 bulan berjumlah 284 orang dengan jumlah sampel sebesar 39 orang. Pengumpulan data diambil pada tanggal 02 Agustus s/d 05 Agustus 2017 yang dibantu oleh enumerator dengan pengolahan data menggunakan uji chi square dan CI (Confident Interval) 95\%.

\section{HASIL DAN PEMBAHASAN}

Tabel 1. Hubungan Antara Pengetahuan dengan Pemberian Imunisasi Campak di Puskesmas Sukakarya Kota Sabang

\begin{tabular}{llcccccccc}
\hline & & \multicolumn{4}{c}{ Pemberian Imunisasi } & \multicolumn{2}{c}{ Uji Statistik } \\
\cline { 3 - 6 } No & Pengetahuan & \multicolumn{3}{c}{ Ada } & \multicolumn{3}{c}{ Tidak } & \multirow{2}{*}{ f } & \multirow{2}{*}{$\boldsymbol{P}$-Value } \\
\cline { 3 - 8 } & & f & $\%$ & f & \% & & & \\
\hline 1 & Baik & 18 & 90 & 2 & 10 & 20 & 100 & \multirow{2}{*}{0.127} \\
2 & Kurang Baik & 13 & 68.4 & 6 & 31.6 & 19 & 100 & \\
\hline
\end{tabular}


Berdasarkan tabel di atas dapat dijelaskan bahwa dari 20 responden dengan pengetahuan baik 90\% ibu ada memberikan imunisasi campak dibandingkan dengan dari 19 responden yang berpengetahuan kurang sebesar $68.4 \%$. hasil uji statistik diperoleh nilai $\mathrm{P}=$ 0,127 , artinya tidak ada hubungan antara pengetahuan dengan pemberian imunisasi campak di Puskesmas Sukakarya Kota Sabang.

\section{Tabel 2. Hubungan Antara Sikap dengan Pemberian Imunisasi Campak di Puskesmas Sukakarya Kota Sabang}

\begin{tabular}{|c|c|c|c|c|c|c|c|c|}
\hline \multirow{3}{*}{ No } & \multirow{3}{*}{ Sikap } & \multicolumn{4}{|c|}{$\begin{array}{c}\text { Pemberian Imunisasi } \\
\text { Campak }\end{array}$} & \multicolumn{3}{|c|}{ Uji Statistik } \\
\hline & & \multicolumn{2}{|c|}{ Ada } & \multicolumn{2}{|c|}{ Tidak } & \multirow{2}{*}{$\mathbf{F}$} & \multirow{2}{*}{$\%$} & \multirow{2}{*}{ P-Value } \\
\hline & & $\mathbf{f}$ & $\%$ & $\mathbf{f}$ & $\%$ & & & \\
\hline 1 & Positif & 25 & 96.2 & 1 & 3.8 & 26 & 100 & \multirow{2}{*}{0.001} \\
\hline 2 & Negatif & 6 & 46.2 & 7 & 53.8 & 13 & 100 & \\
\hline
\end{tabular}

Berdasarkan tabel 4.3 dapat dijelaskan bahwa dari 26 responden sebanyak $96.2 \%$ ibu bersikap positif dengan ada memberikan imunisasi campak sedangkan dari 13 responden ibu bersikap negative sebesar 46.2\%. Hasil uji statistic diperoleh $\mathrm{P}$ value 0.001 , artinya ada hubungan antara sikap dengan pemberian imunisasi campak di Puskesmas Sukakarya Kota Sabang

\section{Tabel 3. Hubungan Antara Dukungan Petugas Kesehatan dengan Pemberian Imunisasi Campak di Puskesmas Sukakarya Kota Sabang}

\begin{tabular}{|c|c|c|c|c|c|c|c|c|}
\hline \multirow{3}{*}{ No } & \multirow{3}{*}{$\begin{array}{l}\text { Dukungan } \\
\text { Petugas } \\
\text { Kesehatan }\end{array}$} & \multicolumn{4}{|c|}{$\begin{array}{c}\text { Pemberian Imunisasi } \\
\text { Campak }\end{array}$} & \multicolumn{3}{|c|}{ Uji Statistik } \\
\hline & & \multicolumn{2}{|c|}{ Ada } & \multicolumn{2}{|c|}{ Tidak } & \multirow[b]{2}{*}{$\mathbf{f}$} & \multirow{2}{*}{$\%$} & \multirow[b]{2}{*}{ P-Value } \\
\hline & & $\mathbf{f}$ & $\%$ & $\mathbf{f}$ & $\%$ & & & \\
\hline 1 & Mendukung & 20 & 100 & 0 & 0 & 20 & 100 & \\
\hline 2 & $\begin{array}{l}\text { Tidak } \\
\text { mendukung }\end{array}$ & 11 & 57.9 & 8 & 42.1 & 19 & 100 & 0.001 \\
\hline
\end{tabular}

Berdasarkan table hubungan antara dukungan petugas kesehatan dengan pemberian imunisasi campak dapat dijelaskan bahwa dari 20 responden, dukungan petugas kesehatan yang mendukung $100 \%$ ibu ada memberikan imunisasi campak, sedangkan dari 19 responden dengan petugas kesehatan tidak mendukung sebanyak 57.9\%. hasil uji statistic diperoleh $\mathrm{P}$ 
value $=0.001$, artinya ada hubungan antara dukungan petugas kesehatan dengan pemberian imunisasi campak di Puskesmas Sukakarya Kota Sabang.

\section{Hubungan antara Pengetahuan dengan Pemberian Imunisasi Campak}

Berdasarkan tabel 4.2 dapat dijelaskan bahwa dari 20 responden dengan pengetahuan baik $90 \%$ ibu ada memberikan imunisasi campak dibandingkan dengan dari 19 responden yang berpengetahuan kurang sebesar $68.4 \%$. hasil uji statistic diperoleh nilai $\mathrm{P}=0,127$, artinya tidak ada hubungan antara pengetahuan dengan pemberian imunisasi campak di Puskesmas Sukakarya Kota Sabang. Penelitian ini sejalan dengan penelitian Destiyanta(2015), bahwa tidak ada hubungan antara pengetahuan dengan pemberian imunisasi campak dengan nilai $\mathrm{P}=0.152$.

Pengetahuan ibu terhadap imunisasi campak berpengaruh secara signifikan terhadap kepatuhan pemberian imunisasi campak hal ini dapat dilihat dari pengetahuan ibu yang dipengaruhi oleh faktor tingkat pendidikan, pekerjaan dan umur ibu menjadi faktor internal yang cukup berpengaruh terhadap kepatuhan dalam pemberian informasi yang jelas mengenai imunisasi campak khususnya ketepatan terhadap pemberian imunisasi campak pada bayi usia (9-12 bulan).

Penelitian ini tidak mempengaruhi pengetahuan ibu yang baik maupun kurang, karena ada beberapa ibu yang berpengetahuan kurang baik memberikan imunisasi campak kepada anaknya, ini dikarenakan ada factor lain yang mempengaruhimya, yaitu factor sikap ibu dan dukungan petugas kesehatan. Sikap ibu yang positf dan adanya dukungan dari petugas kesehatan, membuat ibu tidak takut memberikan imunisasi campak kepada anaknya.

\section{Hubungan antara Sikap dengan Pemberian Imunisasi Campak}

Berdasarkan tabel 4.3 dapat dijelaskan bahwa dari 26 responden sebanyak $96.2 \% \mathrm{ibu}$ bersikap positif dengan ada memberikan imunisasi campak sedangkan dari 13 responden ibu bersikap negative sebesar 46.2\%. Hasil uji statistik diperoleh P value 0.001, artinya ada hubungan antara sikap dengan pemberian imunisasi campak di Puskesmas Sukakarya Kota Sabang.

Sikap yang positif dapat membuat ibu yakin dan tidak takut akan pemberian imunisasi campak kepada anaknya. Ibu yang bersikap positif memiliki pemikiran dengan 
diberikan imunisasi campak, maka seorang anak dapat terhindar dari penyakit campak. Sedangkan ibu yang bersikap negative terhadap imunisasi campak, membuat ibu tidak akan memberikan imunisasi campak kepada anaknya. Banyak ketakutan ibu tidak memberikan imunisasi kepada anaknya dikarenakan ketakutan apabila di imunisasi, maka anaknya akan menagalami demam dan juga takut akan vaksin yang diberikan mengandung zat-zat yang tidak baik bagi tubuh, serta ibu yang bersikap negative juga berfikiran bahwa setiap tubuh anaknya sudah ada imunitas jadi tidak perlu diberikan imunisasi.

\section{Hubungan antara Dukungan Petugas Kesehatan dengan Pemberian Imunisasi Campak}

Berdasarkan table hubungan antara dukungan petugas kesehatan dengan pemberian imunisasi campak dapat dijelaskan bahwa dari 20 responden, dukungan petugas kesehatan yang mendukung $100 \%$ ibu ada memberikan imunisasi campak, sedangkan dari 19 responden dengan petugas kesehatan tidak mendukung sebanyak 57.9\%. hasil uji statistic diperoleh $\mathrm{P}$ value $=0.001$, artinya ada hubungan antara dukungan petugas kesehatan dengan pemberian imunisasi campak di Puskesmas Sukakarya Kota Sabang.

Petugas kesehatan berupaya dan bertanggung jawab, memberikan pelayanan kesehatan pada individu dan masyarakat yang professional akan mempengaruhi status kesehatan masyarakat. Sehingga diharapkan ibu mau mengimunisasikan bayinya dengan memberikan atau menjelaskan pentingnya imunisasi (Suparyanto, 2011).

Dukungan petugas kesehatan dalam pemberian imunisasi campak sangat diperlukan, dengan adanya dukungan petugas kesehatan, seorang ibu termotivasi untuk memberikan imunisasi campak untuk anaknya. Petugas kesehatan juga tidak boleh berhenti dan meyakinkan ibu-ibu untuk memberikan imunisasi kepada anaknya.

\section{KESIMPULAN}

Dari hasil penelitian ini diperoleh kesimpulan adalah ada hubungan antara sikap dan dukungan petugas kesehatan dengan pemberian imunisasi campak karena $\mathrm{P}$ Value $<0.05$, dan tidak ada hubungan antara pengetahuan dengan pemberian imunisasi campak karena $\mathrm{P}$ value $\geq 0.05$. 


\section{SARAN}

1. Meningkatkan pengetahuan masyarakat tentang imunisasi melalui penyuluhan secara individu maupun massal, pemberian informasi mengenai campak melalui Pendidikan Kesehatan Masyarakat (PKM) maupun leaflet.

2. Meningkatkan cakupan imunisasi di masyarakat dan mendeteksi secara dini dan cepat adanya penyakit camapk di masyarakat sehingga tidak terjadi KLB.

3. Melakukan sosialisasi kepada masyarakat agar memanfaatkan program pemerintah dengan memberikan anaknya imunisasi campak sesuai dengan jadwal yang ditentukan, dan jika mengetahui anaknya yang menderita campak maka perlu dilakukan isolasi terhadap kasus untuk mencegah penularan campak.

4. Perlu dilakukan penelitian lanjutan tentang faktor apa saja yang berhubungan dengan imunisasi campak.

\section{DAFTAR PUSTAKA}

Badan Pusat Statistik., (2013). Tabel 3.1.5 Jumlah Penduduk Menurut Kelompok Umur (Ribuan), 2008-2011. Accesed Nov 20 , 2016; http://aceh.bps.go.id/ index.php?r=artikel/view\&id=141

Destiyanta, Aditama Putra.(2015). Hubungan tingkat pendidikan, pekerjaan dan pengetahuan ibu dengan ketepatan jadwal mengikuti imunisasi campak di Wilayah Kerja Puskesmas Weru Sukoharjo. Jurnal : Fakultas Ilmu Kesehatan Universitas Muhammadiyah Surakarta

Direktorat Jendral Pengendalian Penyakit dan Penyehatan Lingkungan.(2015). Data dan Informasi Tahun 2014 (Profil Kesehatan Indonesia). Jakarta

Kementerian Kesehatan RI, (2013). Riset Kesehatan Dasar (RISKESDAS 2013). Badan Penelitian dan Pengembangan Kesehatan Kementerian Kesehatan RI, Jakarta

Luknis Sabri dan Sutanto Priyo.(2013). Statistik Kesehatan. Jakarta: Rajawali Pers.

Notoatmodjo S, (2010). Metodologi penelitian kesehatan. Jakarta : Rineka Cipta

Notoatmodjo, S. (2010). Ilmu perilaku kesehatan. Jakarta: Rineka Cipta.

Suparyanto, (2013) http://dr-suparyanto.blogspot.co.id/2013/04/sekilas-tentang-penyakitcampak.html (Accesed Nov 20 $\left.{ }^{\text {th }}, 2016\right)$

WHO. (2015). Measles Cased Reported By Country 2015 (online). Dari http// apps.who. Into/gho/ (Accesed Nov 20 ${ }^{\text {th }}, 2016$ ) 